$$
\begin{aligned}
& \text { مطالعهُ ساختارى برهم كنش داروى ضدسرطان از دستهُ كميلكس پِلاتينى با آلبومين سرم انسانى }
\end{aligned}
$$

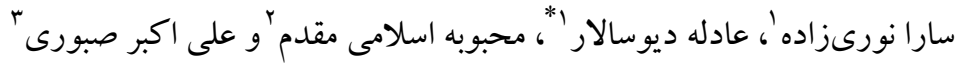

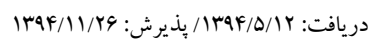

$$
\begin{aligned}
& \text { 'خروه علوم سلولى و مولكولى، دانشكدة علوم زيستى، دانشكاه خوارزمى، تهران }
\end{aligned}
$$

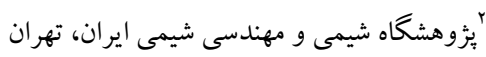

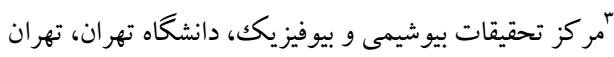

$$
\begin{aligned}
& \text { divsalar@khu.ac.ir :مسئول مكاتبات }
\end{aligned}
$$

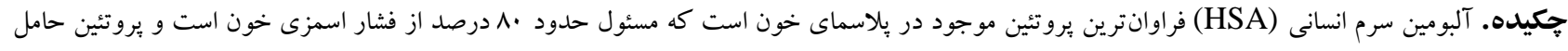

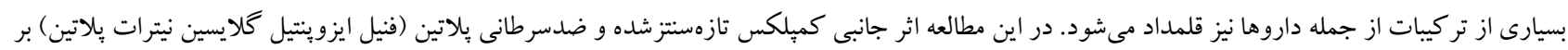

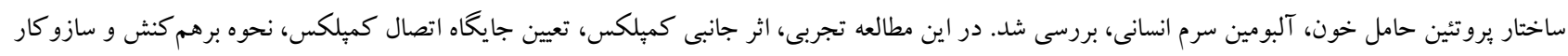

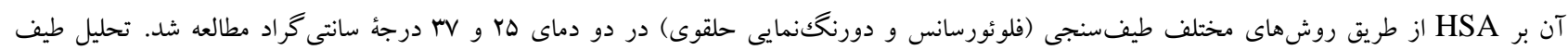

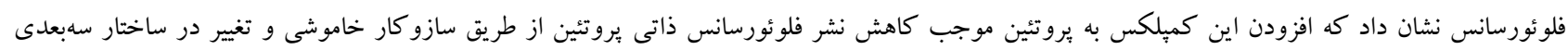

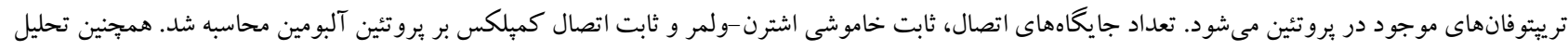

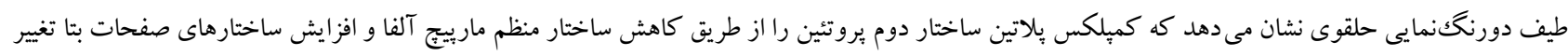

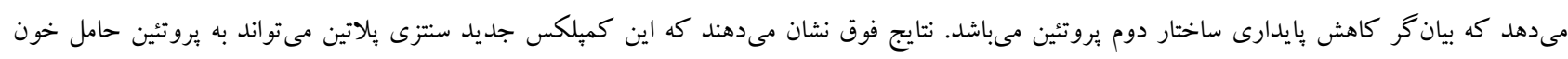

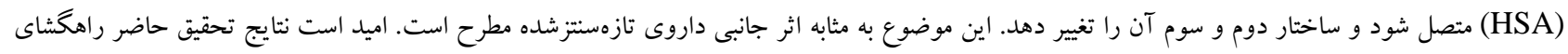

$$
\begin{aligned}
& \text { سنتز و طراحى تركيباتى با عوارض جانبى كمتر در شيمى درمانى باشد. } \\
& \text { وازههاى كليدى. آلبومين انسانى، كميلكس بلاتين، فلوئورسانس، دو رنغكنمايى حلقوى }
\end{aligned}
$$

\section{A structural study on the interaction of the anti-cancer compound of Platinum complex with human serum albumin}

\author{
Sara Noorizadeh $^{1}$, Adeleh Divsalar $^{1 *}$, Mahbubeh Eslami-Moghaddam $^{2}$ and Ali Akbar Saboury ${ }^{3}$
}

Received 03.08.2015/ Accepted 15.02.2016

\begin{abstract}
${ }^{1}$ Department of Cell and Molecular Sciences, Faculty of Biological Sciences, Kharazmi University, Tehran, Iran
${ }^{2}$ Chemistry and Engineer Chemistry Research Center, Tehran, Iran

${ }^{3}$ Institute of Biochemistry and Biophysics, University of Tehran, Tehran, Iran

*Correspondent author: divsalar@khu.ac.ir
\end{abstract}

\begin{abstract}
Human serum albumin (HSA) is the most abundant protein in blood plasma, which is responsible for $80 \%$ of blood pressure; it also acts as a carrier protein for many compounds in the blood such as drugs. In the present study, the interaction and side-effects of a newly-designed anti-cancer compound of isopentyl-glycine1, 10-phenanthroline Platinum nitrate on HSA have been investigated. In this investigation, the side effects, values of the number of binding sites and the association binding constants of new synthesized $\mathrm{Pt}(\mathrm{II})$ complex have been studied by different spectroscopic (fluorescence and circular diachronic (CD) techniques at different temperatures of 25 and $37{ }^{\circ} \mathrm{C}$. The analysis of fluorescence spectra showed that the addition of the complex led to a significant reduction in the fluorescence spectra of HSA via quenching mechanism. Also, it can change the three-dimensional structure of tryptophan existing in the protein. The number of binding sites, the Stern-Volmer quenching constant and the association constant of the complex were calculated on the HSA protein. The analysis of circular dichroic spectra showed that the complex can change the regular secondary structure of the protein via reduction of $\alpha$ helical structure and increase of $\beta$ sheet structure which indicates a decrease in the stability of the protein. According to the results obtained, it can be concluded that this new synthesized Pt(II) complex can bind to the main blood carrier protein (HSA) and change the secondary and tertiary structure of the protein which can be considered as the side-effects of this drug.
\end{abstract}

Keywords. HSA, platinum complex, fluorescence, side effects, thermodynamic parameters 
تومور در آن قرار دارد، مى تواند عامل موثرى در شيمىدرمانى

باشد (Han et al., 2015).

به دليل سمى بودن داروهاى ضدسرطان و انتخاب آنها عليه رشد

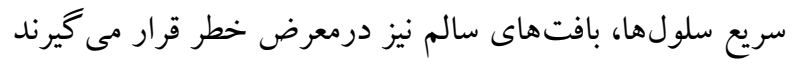
و عوارض جانبى ناخوشايندى از جمله حالت تهوع، ريزش مو،

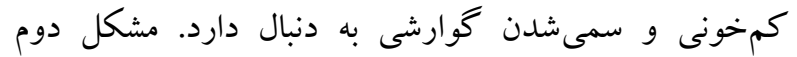
مقاومت سلولهاى سرطانى در برابر داروست كه موجب بايين آمدن ظرفيت و كارايى دارو مىشود. اين دو عامل سمىبودن و

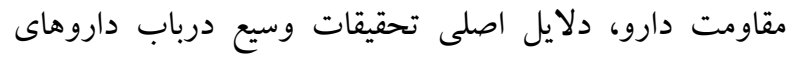
ضدسرطان و بررسى اثر درمانى آنها است (Ho, 2006).

كميلكسهاى فلزى در درمان بسيارى از بيمارىها شامل سرطان، آنمى، آماس مفاصل، التهاب مزمن، عفونت باكتريايى و بيمارىهاى كوارشى كاربرد دارند. داروهاى پِاتينى نقش كليدى بين عوامل ضدسرطان بريايه فلز بازى مى كنند. اولين

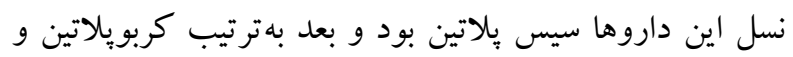

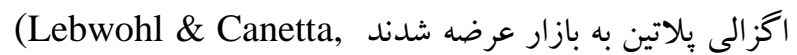

استفاده از داروهاى پياتين (مانند سيسيلاتين) براى درمان سرطان، نشاندهندة تو انايى اين كميلكسهاى فلزى در درمان است. كميلكسهاى فلزى گروه هِلاتينيوم، داراى بتانسيل حمله به سلولهاى سرطانى به منزله آنتى تومور است. به اين منظور، در برد اين تحقيق به بررسى برهم كنش داروى تازهسنتشده (فنيل

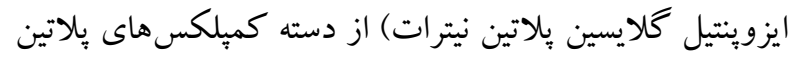

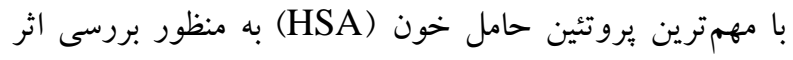
جانبى داروى سنتزى در دماهاى محيط و فيزيولوزيك برداخته

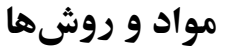

\section{مواد}

آلبومين سرم انسان (HSA) فاقد اسيد خرب با درجهُ خلوص

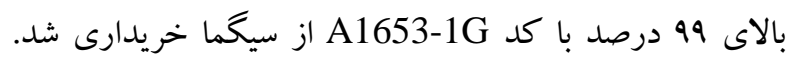
كميلكس فنيل ايزوينتيل گلايسين پِاتين نيترات نيز در آزمايشگاه
آلبومين سرم انسانى (HSA) يكى از اصلى ترين و در عين حال فراوانترين يروتئينهاى موجود در بِلاسماى خون است كه

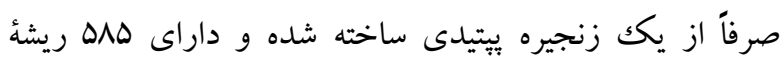

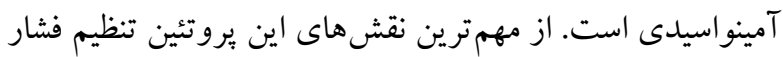

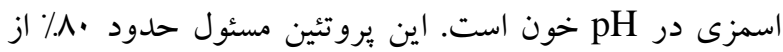
فشار اسمزى خون است؛ بهعلاوه داراى خواص آنزيمى است و همجنين به عنوان يروتئين حامل و مخزن براى بسيارى از تر كيبات ازجمله اسيدهاى جرب، داروها، متابوليتها و يونهاى فلزى عمل مى كند (Ascnzi et al., 2010).

يروتئين آلبومين سرم انسانى يكى از كوجِكت ترين يروتئينهاى موجود در هِاسماى خون است. اندازه و همجنين فراوانى اين يروتئين گوياى اين حقيقت است كه بسيارى از تركيبات

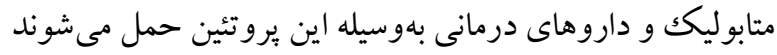
(Iglesias et al., 2015)

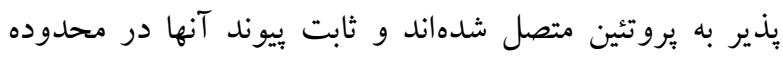
10 -10 $10^{6} \mathrm{M}^{-1}$

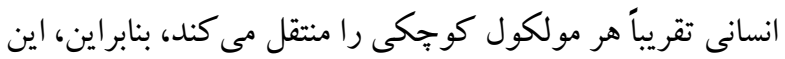

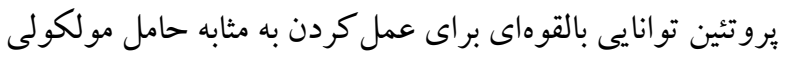

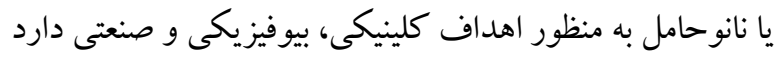

.(Shi et al., 2015)

امروزه روشهاى متعددى ازجمله جراحى، يرتودرمانى و شيمى (Knoll et al., 2015) استفادة همزمان از اين درمانها عليه سرطانهايى بـاني

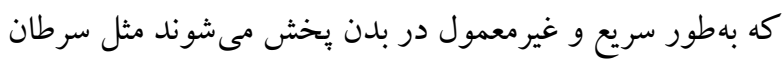
خون به كار گر فته مى شود، اما داروهاى شيميايى علاوهبر سلول

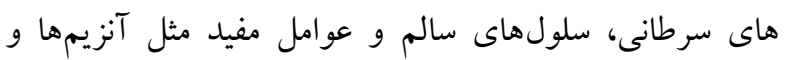

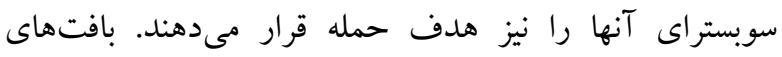
حساس مثل بافت هاى مغز استخوان، دستگاه گوارش و دفع ادرار

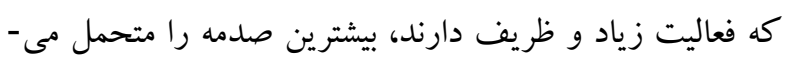

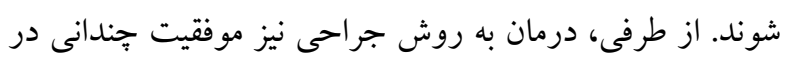

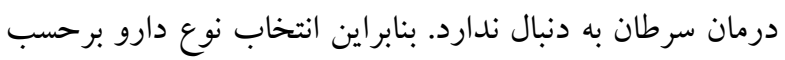

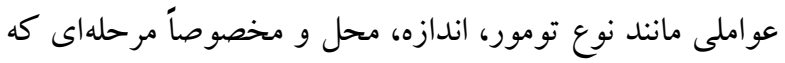


شده است. جهت بررسى تغييرات كمى در محتواى ساختار دوم بروتئين از نرمافزار CDNN استفاده شد.

نتايج

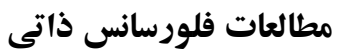

فلورسانس يكك تكنيك بسيار قوى براى مطالعه ساختار،

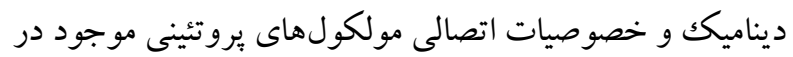

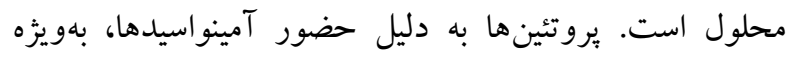
ترييتوفان، تيروزين و فنيل آلانين داراى فلوئورسانس ذاتى است دئ.

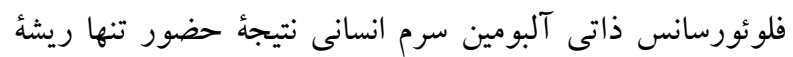
ترييتوفان (Trp-214) در حفرءٔ هيدروفوب است ( Rebwohl

.(\& Canetta, 1998

تغييرات در طيف نشرى فلوئورسانس آلبومين سرم انسانى در غياب و در حضور غلظتهاى مختلف كميلكس بِلاتين در دو

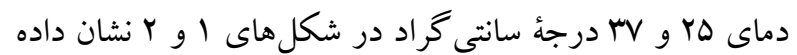

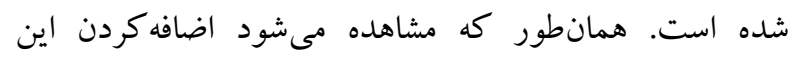

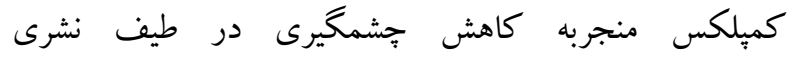
فلوئورسانس Trp214 بروتئين در هر دو دماى دماى محيط و

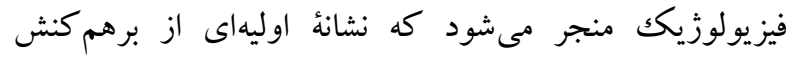

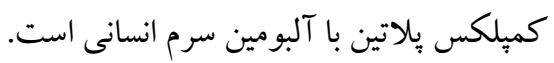

همجِنين شكل ץ نشان مىدهد كه با افزايش غلظت كميلكس كاهش فاحشى در نشر ماكسيمم بروتئين يا خاموشى در نشر

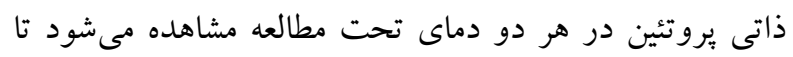

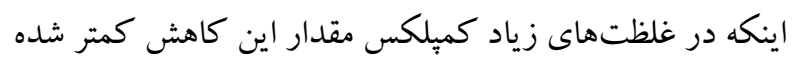

$$
\text { و به حالت اشباع مىرسد. }
$$

شناسايى و سنتز شد. نمك كلريدسديم خريدارىشده از شركت

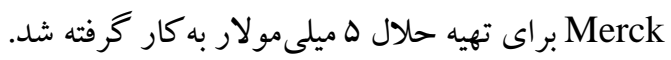

روشها

مطالعات فلوئورسانس

براى بررسى تغييرات ساختار سوم آلبومين سرم انسانى در اثر

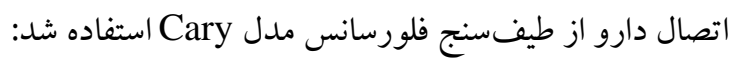
در اين آزمايش، به كووتهاى مخصوص با حجم ل.ها

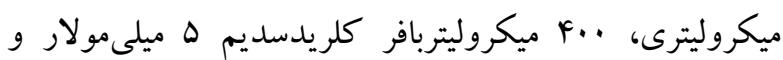

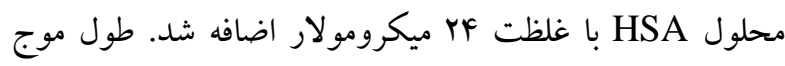

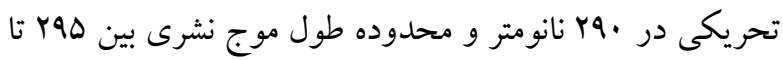
له نانومتر قرار داده شد و آزمايش در غلظتهاى مختلف

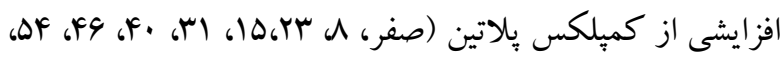

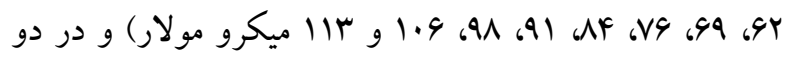

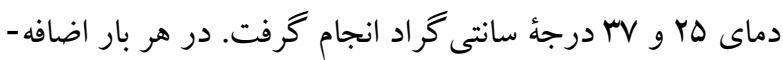
كردن كمٍلكس بِلاتين به مدت r دقيقه با بروتئين آلبومين انكوبه شد. آزمايشها حداقل بار بار تكرار شدند.

\section{مطالعه طيف دورنكَنمايى حلقوى Circular)}

Dichroism)

مطالعهُ دورنگكنمايى حلقوى در ناحيه فرابنفش دور يعنى طول

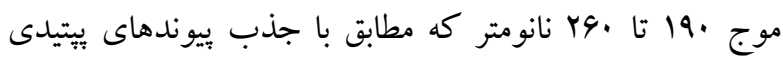

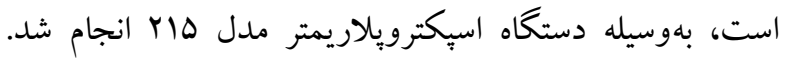
هدف از تحليل مزبور دسترسى به ميزان ساختارهاى دوم منظم

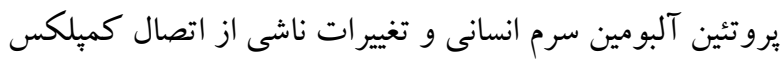

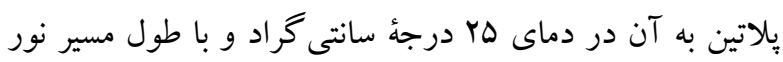

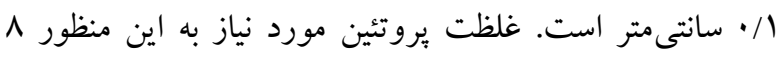

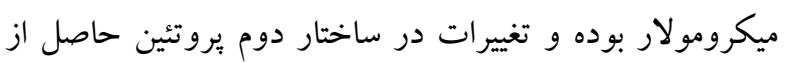

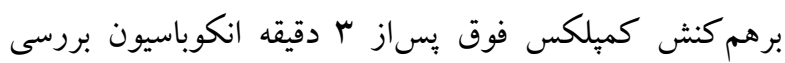




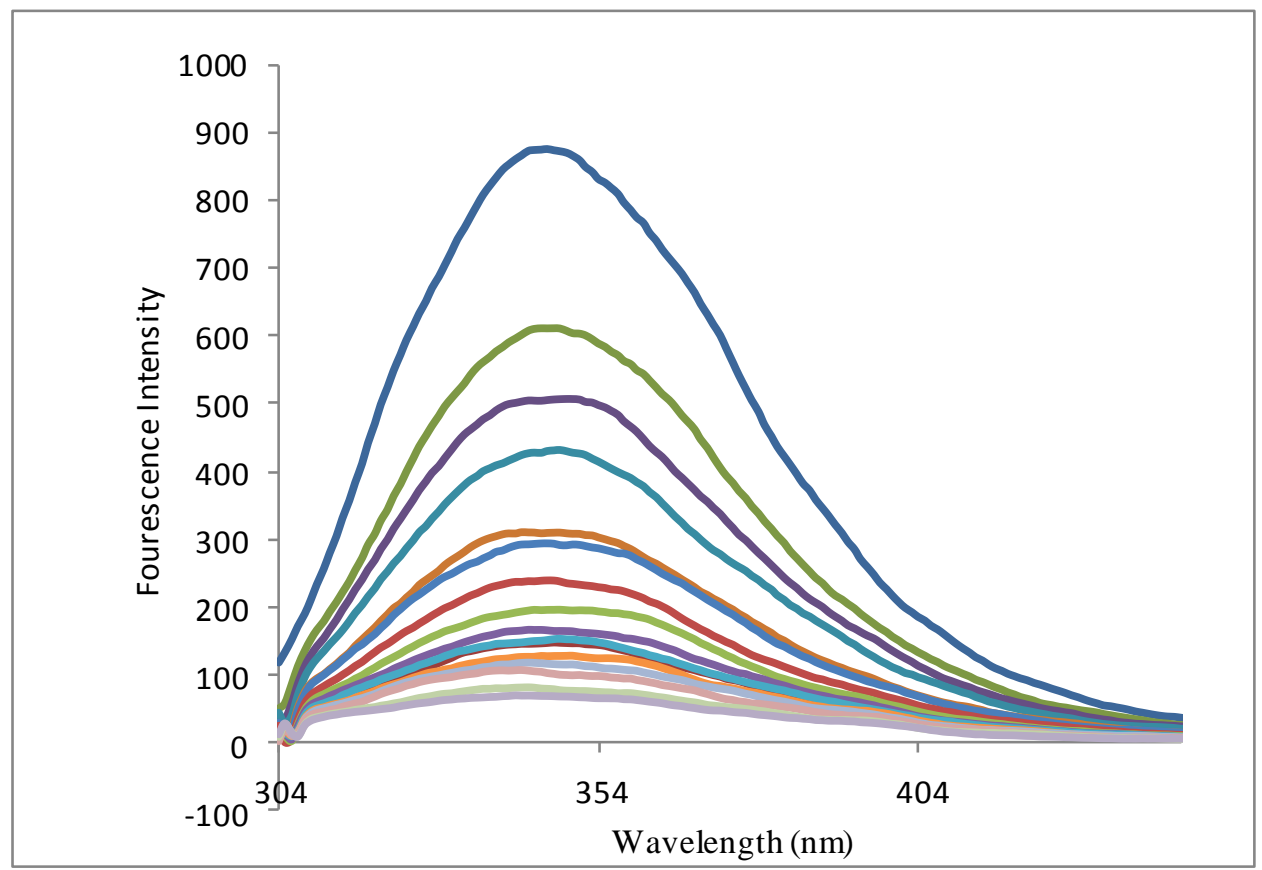

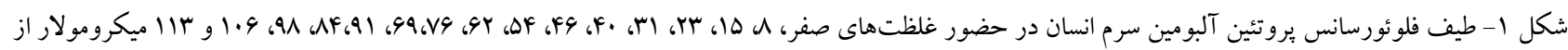

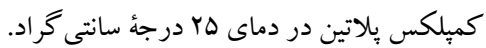

Fig. 1. The fluorescence spectra of human serum albumin in the presence of various concentration of Pt complex $(0,8$, $15,23,31,40,46,54,62,69,76,84,91,98,106,113 \mu \mathrm{M})$ at $25^{\circ} \mathrm{C}$.

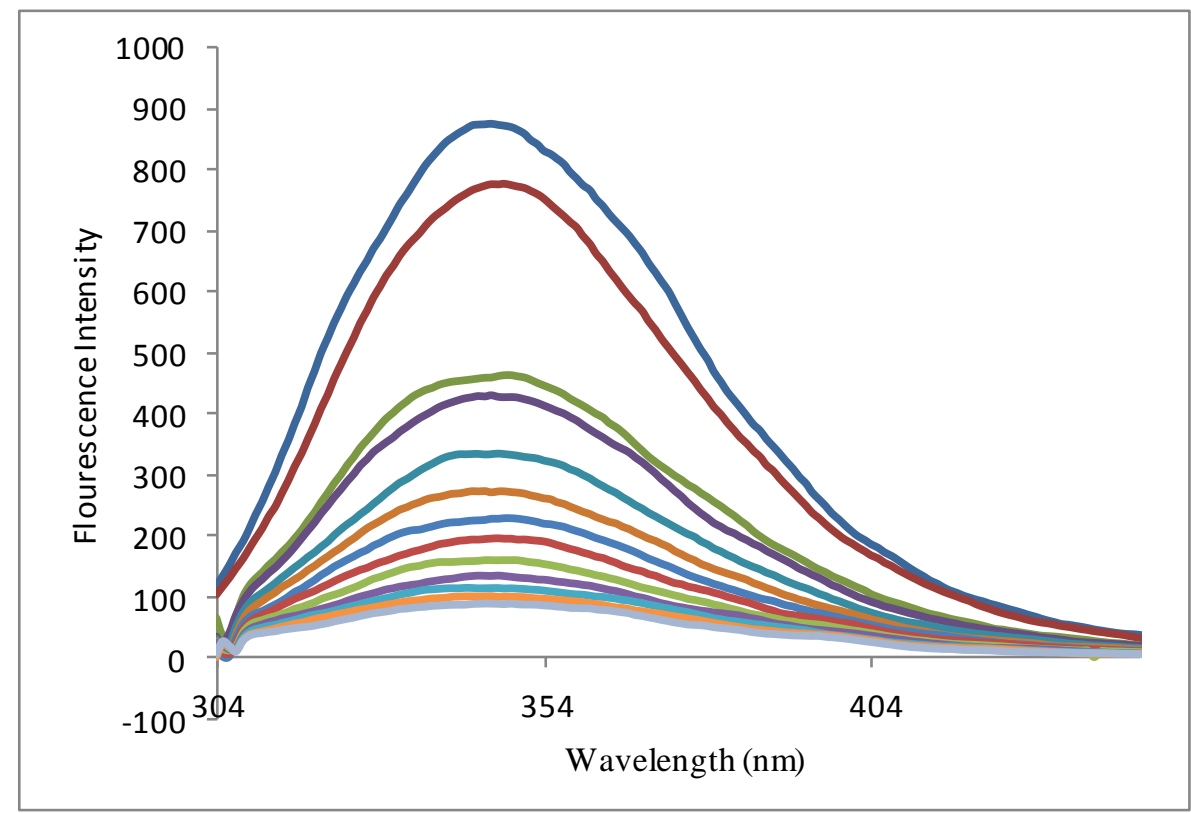

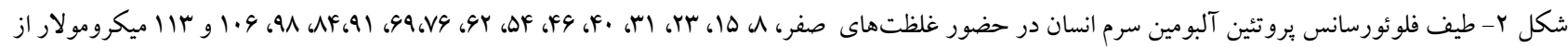

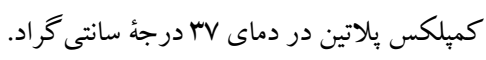

Fig. 2. The fluorescence spectra of human serum albumin in the attendance of various concentration of Pt complex ( 0 , $8,15,23,31,40,46,54,62,69,76,84,91,98,106,113 \mu \mathrm{M})$ at $37{ }^{\circ} \mathrm{C}$. 


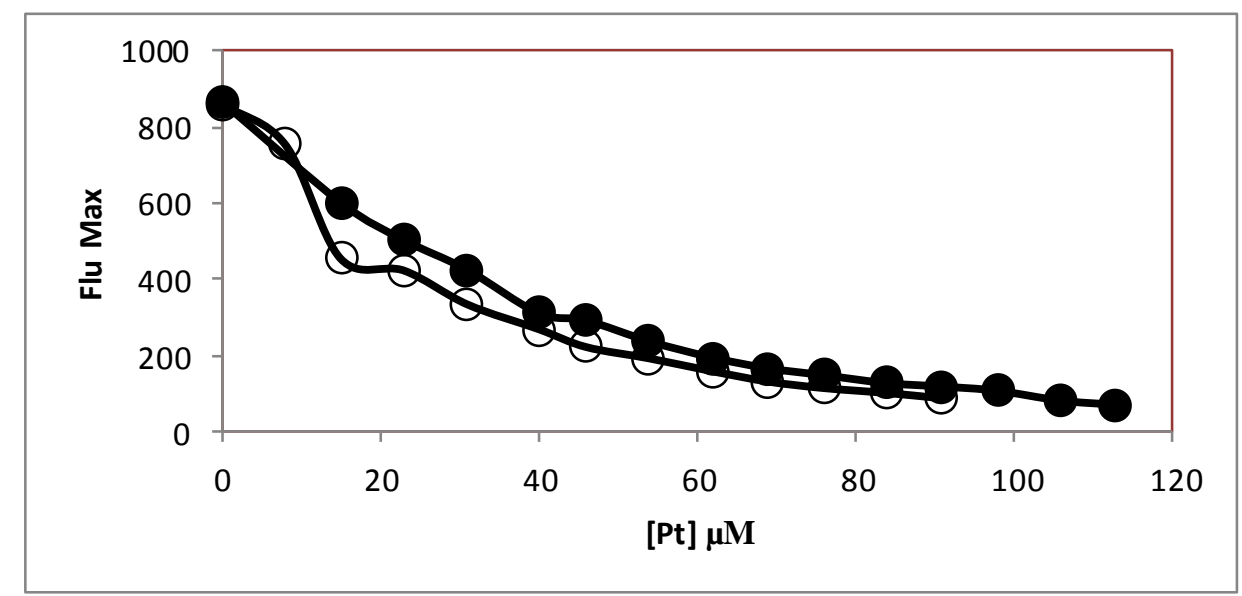

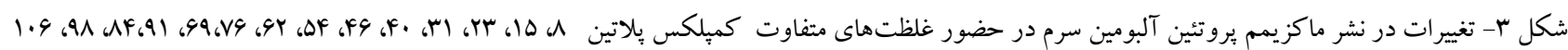

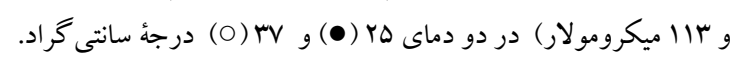

Fig. 3. Changes in maximum fluorescence intensity of HSA in the presence of different concentrations of Pt (II) complex $(8,15,23,31,40,46,54,62,69,76,84,91,98,106,113 \mu \mathrm{M})$ at different temperatures of $27(\bullet)$ and $37{ }^{\circ} \mathrm{C}$ (O).

منحنى غيرخطى اشترن ولمر مى تواند نتيجه تر كيبى ازسازو كار خاموشى از نوع استاتيك و ديناميكك يا بهعلت غلظت بالاى ليخاندهاى اطراف فلوروفور باشد ( Giovagnini et al.,

$$
\text { 2005) كه در شكل f مشاهده مى شود. }
$$

$$
\mathrm{F}_{0} / \mathrm{F}=1+\mathrm{K}_{\mathrm{sv}}[\mathrm{Q}]
$$$$
\text { در معادلة فوق، F و F بهترتيب مبين شدت نشر فلوئورسانس }
$$

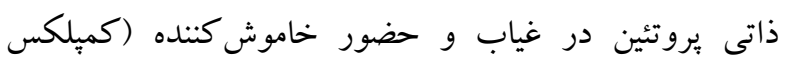

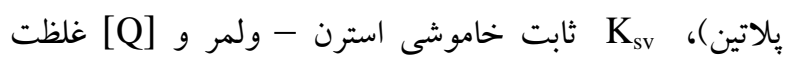$$
\text { خاموش كننده است. }
$$

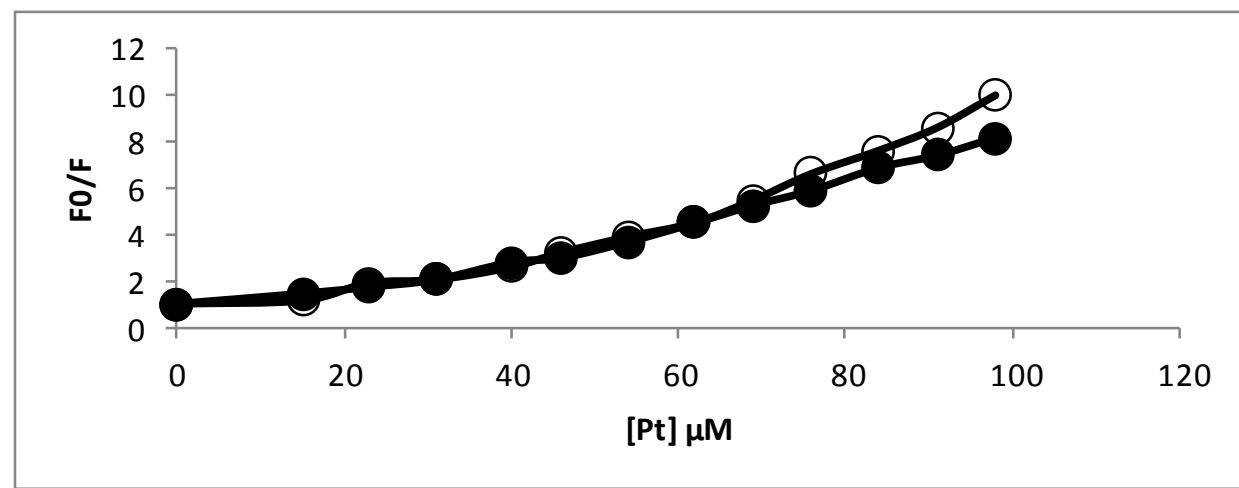

$$
\text { شكل F- نمودار اشتر ن-ولمر F0/F در مقابل خاموش كننده [Q] در دو دماى هץ (•) و و (O F (O) درجة سانتى كراد. }
$$

Fig. 4. The Stern-Volmer plots of the interaction between Pt (II) complex and quencher at 25 (•) and $37^{\circ} \mathrm{C}(\mathrm{O})$. 
مىيابد كه نشاندهندهُ سهم بالاى سازو كارهاى خاموشى از نوع استاتيك است.

مقادير fa fa

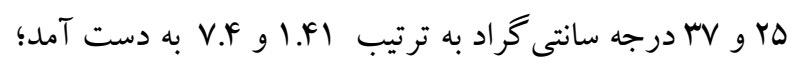

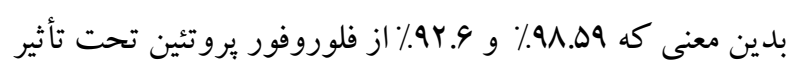

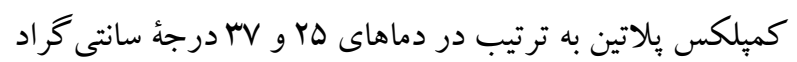
قرار كرفته است.
جهت تخمين دقيق نوع سازو كار خاموشى و مقادير ثابت خاموشى اشترن- ولمر در دو دما، از معادله اصلاحشده استرنولمر (معادله Y) استفاده شد (Zhang et al., 1998):

$\mathrm{F}=\mathrm{F}_{0} / \mathrm{F}_{0}-\mathrm{F}=1 / f_{\mathrm{a}} \mathrm{K}_{\mathrm{sv}}[\mathrm{Q}]+$

$\mathrm{F}_{0} / \Delta 1 / f_{\mathrm{a}}$

كه در اين معادله fa كسرى از فلورسانس اوليه است كه در دسترس خاموش كننده قرار دارد.

همانطوركه شكل ه نشان مىدهد نمودار F

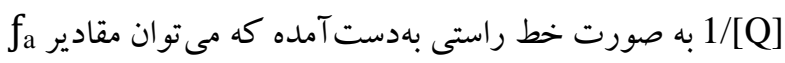
و K را به ترتيب از مقادير عرض از مبدأ و شيب اين نمودار به دست مى آيد. همجِنين مقدار ثابت خاموشى استرن - ولمر محاسبه شده و در جدول ا آمده است. همانطور كه مشاهده مىشود اين مقدار بهشدت وابسته به دماست. به بيان ديخر، با

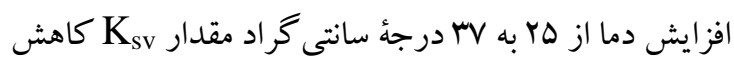

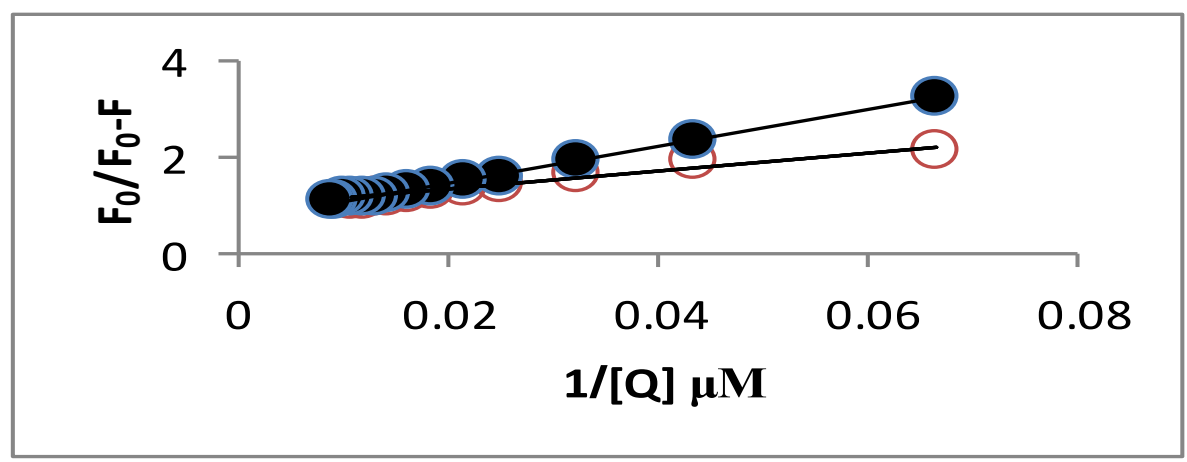

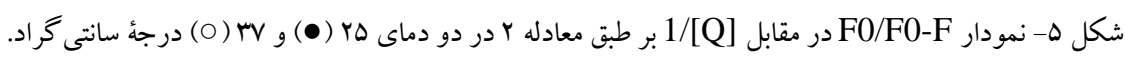

Fig. 5. Changes of F0/F0-F against 1/[Q] according equation number 2 at different temperatures of $25(\bullet)$ and 37 (०) ${ }^{\circ} \mathrm{C}$.

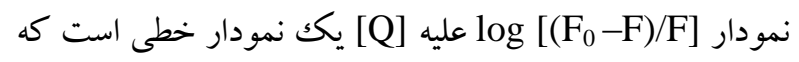
شيب اين نمودار برابر با تعداد جايكاههاى اتصال و عرض از مبدأ آن نيز برابر با log K است (شكل 9).

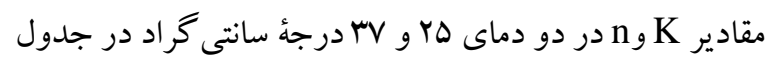
اليست شدهاند.
جهت دستيابى به بِارامترهاى مختلف اتصال كميلكس پِلاتين و HSA

.(Wang et al., 1996)

$\log \left[\left(\mathrm{F}_{0}-\mathrm{F}\right) / \mathrm{F}\right]=\log \mathrm{K}+\operatorname{nlog}[\mathrm{Q}]$ 
ثابت اتصال با افزايش دما مبين گرمازا بودن برهم كنش بين كمبلكس بِلاتين و آلبومين سرم انسان است.
همانطور كه مشاهده مى شود مقدار n در هر دو دما تقريباً برابر

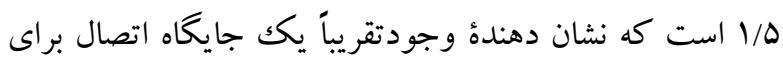

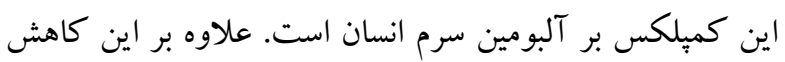

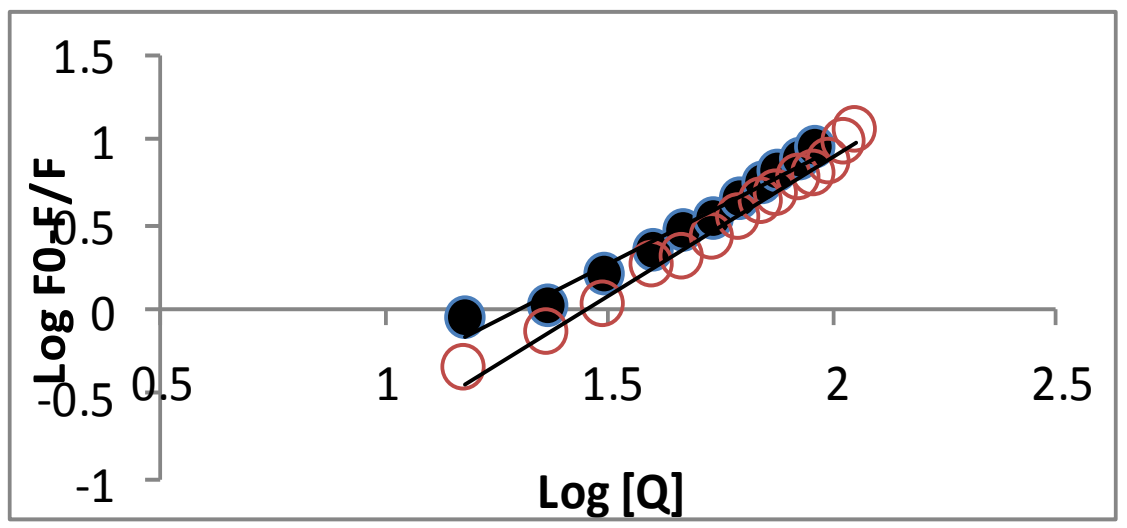

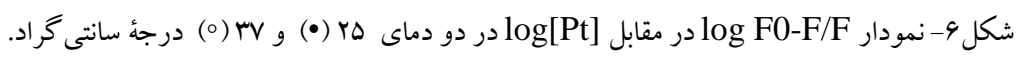

Fig. 6. The $\log \mathrm{F} 0-\mathrm{F} / \mathrm{F}$ against $\log [\mathrm{Pt}]$ at different temperatures of $25(\bullet)$ and $37(\circ){ }^{\circ} \mathrm{C}$.

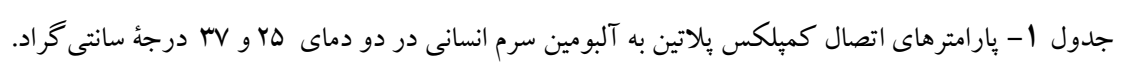

Table 1. Binding parameters of the Pt (II) complex interaction with human serum albumin at different temperatures of 25 and $37^{\circ} \mathrm{C}$.

\begin{tabular}{|c|c|c|c|c|}
\hline دما (درجؤ سانتى كراد) & $\mathbf{K}_{\mathrm{Sv}}\left(\mu \mathbf{M}^{-1}\right)$ & $f_{a}$ & $\mathbf{K}\left(\mu \mathbf{M}^{-1}\right)$ & n \\
\hline ro &.$/ .11$ & $1 / F V$ &.$/ \cdots \Delta$ & $1 / \Delta$ \\
\hline$r v$ & $/ \cdot r r$ & $V / F$ & $\bullet \cdot \cdot v$ & $1 / 9$ \\
\hline
\end{tabular}

حضور غلظتهاى مختلف كميلكس در دماى كه درجهُ سانتى مطالعات دورنكنمايى حلقوى

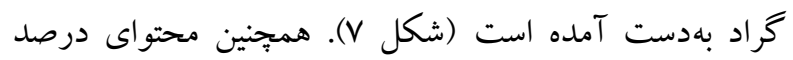

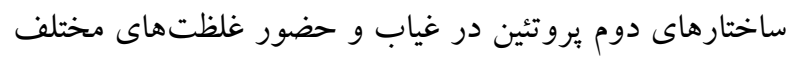

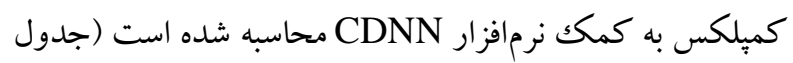

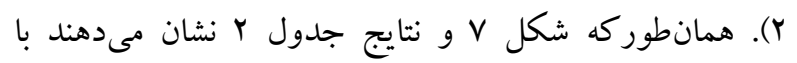
افزايش غلظت كميلكس تغييرات فاحشى در محتواى ساختار دوم آلبومين همراه با كاهش درصد مارييج آلفا و افزايش

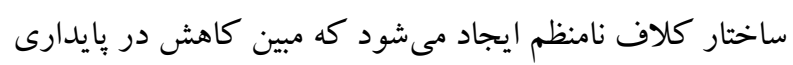
ساختار منظم دوم آلبومين در اثر اين دارو است. طيفسنجى دورنگكنمايى حلقوى مى تواند به صورت حساسى

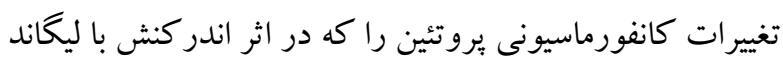

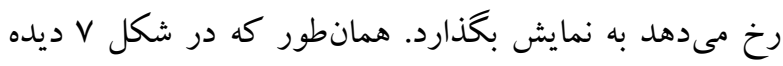
مىشود طيف CD آلبومين سرم داراى دو مينيمم در طول موج -

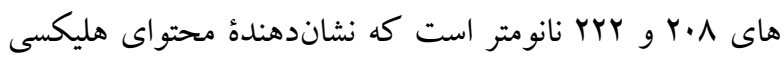

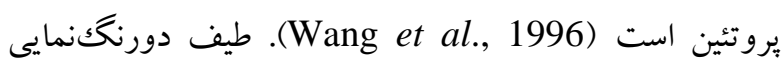
حلقوى آلبومين سرم انسان در ناحيه فرابنفش دور در غياب و 


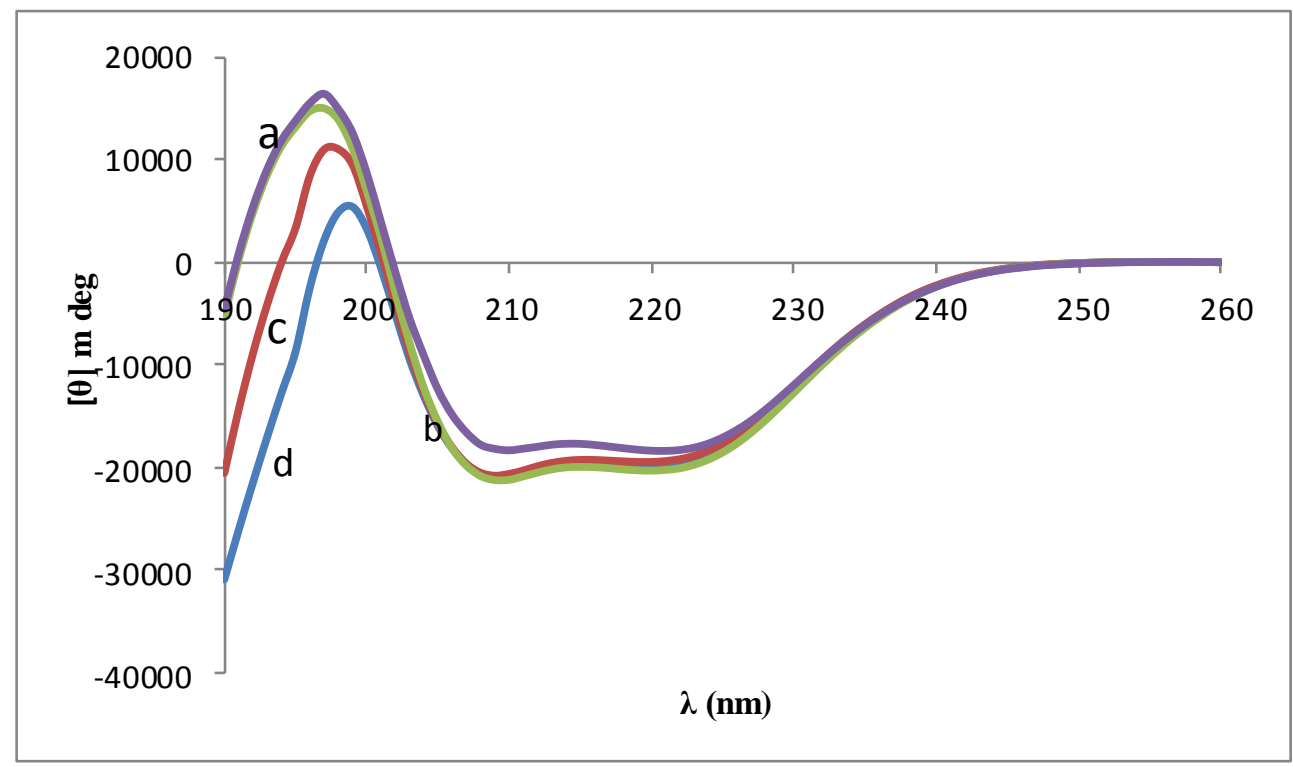

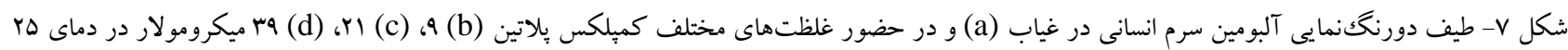
درجهُ سانتى گر اد.

Fig. 7. Far-UV-CD spectra of HSA in (a) the absence; (b-d) in the presence of various concentration of Pt (II) complex [9 (b), 21 (c) and 39 (d) $\mu \mathrm{M}]$ at $25^{\circ} \mathrm{C}$.

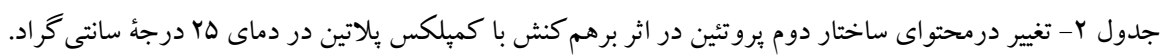

Table 2. Changes in the secondary structure of protein upon interaction with $\mathrm{Pt}$ (II) complex at $25^{\circ} \mathrm{C}$.

\begin{tabular}{|c|c|c|c|}
\hline Complex $(\mu \mathrm{M})$ & $\alpha$-helix $\%$ & $\beta$-sheet \% & Random coil \% \\
\hline . & $k \cdot / \Delta$ & $10 / 1$ & $r Y / F$ \\
\hline 9 & $\mathrm{FV} / \mathrm{F}$ & $\mid F / V$ & $r \cdot / r$ \\
\hline rI & $\Delta r / r$ & $\mid F / \Lambda$ & $1 N / 0$ \\
\hline rq & $\mathrm{FV} / \mathrm{q}$ & $\mid F / F$ & $r Y / Q$ \\
\hline
\end{tabular}

گ گوانوزين باعث ايجاد اختلال در همانندسازى DNA شده و به

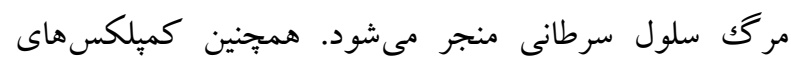
بِاتين در دوزهاى بالا مىتوانند با تركيبات درون سلول نظير Zلو تاتيون و مولكول هاى حاوى گُ گرد واكنش دهند ( .(et al., 1998

برهم كنش بين كميلكس هاى يِلاتين با بروتئين هاى حامل مثل كميلكسهاى سيس پِلاتين و كربوِلاتين به فراوانى در درمان برخى از تومورهاى انسانى مانند سرطانهاى تخمدان، بيضه، ريه، Mansouri-Turshizi et ) مثانه، سر و گردن كاربرد دارند (al., 1992 ) اما مصرف داروهاى يلاتين با برخى عوارض جانبى نر

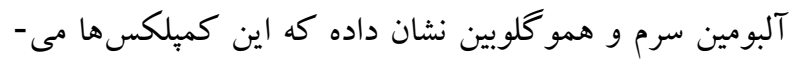
مثل ايجاد سميت در نفرون ها همراه است. مطالعات قبلى نشان داده كه اتصال كميلكس هاى بِلاتين به نيتروزنهاى N7 دو باز 


$$
\begin{aligned}
& \text { يروتئين حامل داروها در خون، كاهش بايدارى يروتئين مذكور } \\
& \text { ازطريق كاهش مقدار ساختارهاى منظم آلفا هليكس در يروتئين } \\
& \text { مشاهده شد، همين تغيير ايجادشده در ساختارهاى دوم و سوم }
\end{aligned}
$$

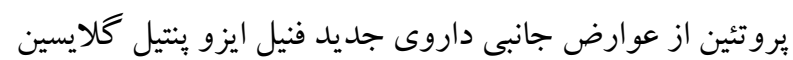$$
\text { است. }
$$$$
\text { نتيجه كيرى }
$$

نتايج بيش كفته نشان مىدهند كه اين كميلكس جديد سنتزى يّاتين مىتواند به يروتئين حامل خون (HSA) متصل شود و ساختار دوم و سوم آن را تغيير دهد و با كاهش ساختارهاى آلفا هليكس درون يروتئين باعث بايدارى كمتر آلبومين سرم شود كه اين موضوع اثر جانبى داروى تازهسنتزشده است. اميد است كه نتايج تحقيق حاضر راهشاى سنتز و طراحى تركيباتى با عوارض جانبى كمتر و مؤثرتر در شيمىدرمانى و نويدبخشى براى بيمار ان سرطانى باشد.

\section{سياسگز ارى}

بدينوسيله نهايت تشكر و قدردانى خود را از معاونت محترم يززوهشى دانشگاه خوارزمى بهدليل حمايت مالى از تحقيق حاضر اعلام مى كنيم.

\section{References}

Ascnzi, P. and Fasano, M. 2010. Allostery in a monomeric protein: The case of human serum albumin. - Biophysical Chemistry 148: 16-22.

Asha, J.M., Selvaraj, S., Paramaguru, G., Venuvanalingam, P. and Renganathan, R. 2011. Spectroscopic and molecular docking investigations on the intraction of Rutin with bovine serum albumin. Zeitschrift Fur Physikalische Chemie. 225: 441-454.

Bertucci, C. and Domenici, E. 2002. Reversible and covalent binding of drugs to human serum albumin. Methodological approaches and physiological relevance. - Curr. Med. Chem. 9: 1463-1481.

$$
\begin{aligned}
& \text { توانند بهطور قابل توجهى ساختار و عملكرد يروتئينهاى حامل } \\
& \text { خود را تغيير دهند و اين خود كوياى عوارض جانبى فراوان آنها } \\
& \text { است. با اين حال اطلاعات كمى درباره برهم كنش كميلكسهاى } \\
& \text { ضدسرطانى بِلاتين وجود دارد. }
\end{aligned}
$$

همجينين Miklášová و همكارانش (2012) اثر برخى كميلكس هاى پِالاديمى و بِلاتينى را بر سلولهاى سرطان كبدى

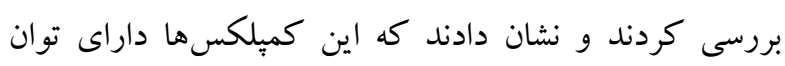
القاى مرگك برنامهريزىشده سلولى هستند و القاى مرگك برنامه ريزىشده سلولى در سلولها با افزايش آسيبهاى DNA و افزايش ظرفيت تشكيل كراسلينك ها با DNA مارييج دورشته -

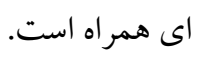

در تحقيقات گذشته اثر مشتق ديخرى از كميلكس پِلاتين (rو r بى بيريدين بوتيل گلايسينتو بِاتين نيترات ) بر ساختار آلبومين. انسانى بررسى شد كه نتايج مبين افزايش پيايدارى ساختار آلبومين انسانى در حضور اين كميلكس بودهاند ( Divsalar et (al., 2010 در تحقيقى ديگر اثر كميلكس بوتيلدى تيو كربامات پِالاديوم بر آلبومين سرم انسانى نيز نشان داد كه اين كميلكس با كاهش ساختار آلفا هليكس پروتئين از پايدارى مى كاهد (Mansouri-Torshizi et al., 2003)، كه در توافق با يافتهاى تحقيق حاضر است. در اين تحقيق نيز با تمركز بر تأثيرات مشتق جديد و تازه سنتزشدهاى از كميلكس فنيل بلاتين بر :بروتئين آلبومين سرم انسانى، به منزله مهمترين

Divsalar, A., Saboury, A.A., Ahadi, L., Zemanatiyar, E. and Mansouri-Torshizi, H. 2010. Investigation of effects of newly synthesized Pt(II) complex against human serum albumin and leukemia cell line of K562. BMB Reports 43: 766-771.

Divsalar, A., Bagheri, M.J., Saboury, A.A., MansooriTorshizi, H. and Amani, M. 2009. Investigation on the intraction of newly designed anticancer $\mathrm{Pd}(\mathrm{II})$ complexes with different aliphatic tails and human serum albumin. - J. Phys. Chem. B. 113: 14035-14042.

Giovagnini, L., Marzano, C., Bettio, F. and Fregona, D. 2005. Chemical and biological profiles of novel 
copper (II) complexes containing S-Donor ligands for the treatment of cancer. - J. Inorg. Biochem. 99: 21-39.

Han, X., Sun, J., Wang, Y. and He, Z. 2015. Recent advances in platinum (IV) complex-based delivery systems to improve Platinum (II) anticancer therapy. - Med. Res. Rev. 35: 68-99.

Ho, J.W. 2006. Potential and cytotoxicity of cisplatinum complex with antitumor activity in combination therapy. - Recent. Patent. Anti-cancer Drug Discovery 1: 129-134.

Iglesias, B.A., Barata, J.F., and Pereira, P.M. 2015. New platinum (II)-bipyridyl corrole complexes: Synthesis, characterization and binding studies with DNA and HSA. - J. Inorg. Biochem. 153: 32-41.

Knoll, J.D. and Turro, C. 2015. Control and utilization of ruthenium and rhodium metal complex excited states forphotoactivated cancer therapy. -Coord. Chem. Rev. 282: 110-126.

Kragh-Hansen, U. 1990. Structure and ligand binding properties of human serum albumin. - Dan-Med-Bull. 37: $57-84$.

Lebwohl, D. and Canetta, R. 1998. Clinical development of platinum complexes in cancer therapy. - Europe Journal Cancer 34: 1522-1534.

Mansouri-Torshizi, H., Srivastava, T.S., Perekh, H.K. and Chitnis, M.P. 1992. Synthesis, spectroscopic, cytotoxic, and DNA binding studies of binuclear 2,2'bipyridine-platinum(II) and-palladium(II) complexes of meso- alpha, alpha' -diaminoa -dipic and meso alpa, alpha'-diaminosuberic acids. - J. Inorg. Biochem. 45: 135-148.

Miklášová, N., Fischer-Fodor, E., Lönnecke, P., Ionut Tomuleasa, C., Virag, P., Perde Schrepler, M., Mikláš, P., Silaghi Dumitrescu, L. and Hey-Hawkins, E. 2012. Antiproliferative effect of novel platinum (II) and palladium (II) complexes on hepatic tumor stem cells in vitro. - Eur. J. Med. Chem. 4: 41-47.

Rosenberg, B., Van Kamp, L., Trosko, J.E. and Mansour, V.H. 1996. Platinium compounds: a new class of potent anti-tumor agents. - Nature 222: 385386.

Sabin, H. and Sadler, J. 2009. Current applications and future potential for bioinorganic chemistry in the development of anticancer drugs. - Drug Discovery Today 14: 23-24.

Shi, H., Cheng, Q., Yuan, S., Ding, X., Liu Y. 2015. Human serum albumin conjugated nanoparticles for $\mathrm{pH}$ and Redox-responsive delivery of a prodrug of Cisplatin. - Chemistry J. 46: 9-21.

Wang, K., Lu, J.F. and Li, R.C. 1996. The events that occur when Cisplatin encounters cells. - Coord. Chem. Rev. 151: 53-88.

Zhang, Q., Zhong, W., Xing, B., Tang, W. and Chen, Y. 1998. Binding properties and stoichiometries of a palla-dium(II) complex to metallothioneins in vivo and in vitro. - J. Inorg. Biochem. 72: 195-200.

Noorizadeh, S., Divsalar, A., Eslami-Moghaddam, M. and Akbar Saboury, A.A. 2016. A structural study on the interaction of the anti-cancer compound of Platinum complex with human serum albumin. - Nova Biologica Reperta 2: 250-259.

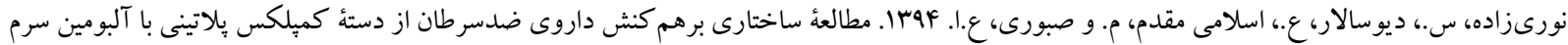

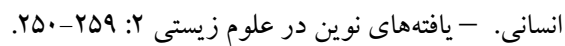

